\title{
Effects of Replacement of Fishmeal with other Alternative Plant Sources in the Feed on Proximate Composition of Muscle, Liver and Ovary in Tilapia (Oreochromis nioloticus)
}

\author{
Khalid Al-Ghanim ${ }^{1}$, Ahmed Al-Thobaiti', Humoud F. Alkahem Al-Balawi', Zubair \\ Ahmed ${ }^{1}$; Shahid Mahboob ${ }^{1}$,*. \\ ${ }^{1}$ Department of Zoology, College of Science, P.O. Box 2455, King Saud University, Riyadh 11455, Saudi Arabia; ${ }^{2}$ \\ Department of Zoology, Government College University Faisalabad, Pakistan.
}

\begin{abstract}
The major objective of this experiment was to assess the effect of alternate plant protein sources as a replacement for fish meal in feed on the proximate composition of muscle, liver and tissue in Oreochromis niloticus. O. niloticus of average size (average Weight $45.00 \pm 1.25 \mathrm{~g}$, total length $13.28 \pm 1.42 \mathrm{~cm}$ ) were stocked in 100 L glass aquarium. Fish were fed with three experimental feeds $(A, B$ and $C)$ and reference commercial feed $(D)$ for 16 weeks. Feed $A$, $B$ and $C$ was prepared from four different plant sources and fish meal (40\% crude protein). Fish were fed at the rate $3 \%$ of body weight daily. It has been observed that tilapia fed with feed B in which $20 \%$ fish meal was replaced compared to feed $C$ with other plant sources of protein, had shown significantly higher total protein in their muscle compared to diet other experimental and commercial feeds. In O. niloticus minimum lipid content was recorded in fish fed with diet B compared to A, C and commercial feed. It has been concluded that 20-40\% level of fish meal can be replaced in the diet of fish without having any impact on growth and chemical composition of muscle.
\end{abstract}

Key Words: Feed; Plant sources; muscle; liver; ovary

* Author for correspondence: 


\section{INTRODUCTION}

The problem of quality food shortage has become critical during the present era of unprecedented population explosion. The rapid increase in world population is creating various problems. The malnutrition and shortage of food is one of the most important problem in terms of quantity and quality of animal protein [1]. Particularly, the rate of intake of animal protein is low. The demand of red meat and poultry meat has tremendously increased. In order to overcome this untoward situation and to save the population from malnutrition in developing countries, there is a dire need to explore alternate sources of animal protein.

Fish is currently considered as one of the best inexpensive alternative sources of high quality animal protein. Fish provides the comparative good quantity of an essential amino acids, minerals and fatty acids as compared to other animal sources of protein [2]. The production of quality protein from fish is based on the development of the fisheries sector. Fish provides a valuable constituent which is required for a balanced and healthy diet due to the presence of low carbohydrate and unsaturated fat contents. It is generally emphasized by the doctors to heart patients for intake of more fish because it is an excellent source of Omega 3. So the preference for fish in our diet may provide a valuable source of an animal protein for the healthy growth and development [4-7]. Fish production is expected to increase many folds and this will need higher production of fish feeds. The inclusion of plant-protein sources in fish feeds were increased due to the limited supply and an increasing cost of fishmeal being a chief constituent of fish feed [8-10]. One of the major challenges of the feed manufacturers is to reduce fishmeal levels in their feed and to substitute it with other alternative sources with and to reduce the cost of production [12].

Fisheries is relatively new sector and promising industry in Saudi Arabia. It started during the early 1980s, when a few farmers started culture tilapia in small water reservoirs. Nile tilapia (Oreochromis niloticus) is a major fish produced from such resources until 2000. Later shrimp, large quantities of shrimp were produced commercially. Nile tilapia (Oreochromis niloticus) is mainly cultured in freshwater, where it is also used for agricultural crop irrigation (Fisheries Statistics, 2008). An optimal dietary protein level in fish feed is an important for fish growth and quality of protein. The objective of this study was to investigate an effect of replacement of fish meal with other alternative source protein on proximate composition in muscle, liver and ovary of Oreochromis niloticus in the local conditions.

\section{MATERIALS AND METHODS}

\subsection{Culture facility, experimental fish and growth trial}

The study was conducted in ten glass aquaria (100 L capacity) containing $70 \mathrm{~L}$ of dechlorinated tap water for a period of 15 days. Fingerlings of tilapia were procured from King Abdul Aziz City of Science and Technology, Riyadh, Saudi Arabia. Total 200 live female specimens of Oreochromis niloticus (average Weight $45.00 \pm 1.25 \mathrm{~g}$, total length $13.28 \pm 1.42 \mathrm{~cm}$ ) were stocked in each aquarium. Water was renewed four times per week. Water was continuously aerated with air pumps. The quality of the water was kept constant. Water temperature and dissolved oxygen were maintained at $22{ }^{\circ} \mathrm{C}$ and $7.5 \mathrm{mg} \mathrm{L}^{-1}$. $\mathrm{pH}$ and ammonia were monitored during the experimental period.

2.2 Preparation of Feed:

Three iso-protein (40\% crude protein) were prepared from different ingredients viz., fish meal, corn gluten meal, wheat gluten meal and bagasse kenna meal (Table 1). Fish feed was prepared in the form of pellets $\left(2 \mathrm{~mm}\right.$, diameter), dried at $60{ }^{\circ} \mathrm{C}$ and 
stored at $4{ }^{\circ} \mathrm{C}$ using commercial manufacturing technology [11]. The prepared feed was stored in plastic lined paper bags at room temperature until fed. The control fish fed with a commercial tilapia feed (40\% crude protein) purchased from Arasco, Saudi Arabia. At the beginning of the feeding trial, all fish were starved for $24 \mathrm{~h}$ and pooled in a big tank. At the beginning of the experiment 5 fishes were sacrificed for the proximate composition of fish flesh. Fish were fed at $3 \%$ body weight daily to apparent satiation twice a day (8:00 and 15:00) for 12 weeks. Uneaten diets were removed / siphoned $1 \mathrm{~h}$ after feeding and then dried and re-weighted.

Table 1: Composition of experimental feed (Crude Protein 40\%)

\begin{tabular}{|c|c|c|c|}
\hline Feed ingredients/1000gm & Feed-A & Feed-B & Feed-C \\
\hline Fish meal & 189.7 & 151.76 & 113.82 \\
\hline Soybean meal & 170.0 & 170.0 & 207.94 \\
\hline corn gluten meal & 175.5 & 213.44 & 213.44 \\
\hline wheat gluten meal & 203.0 & 203.0 & 203.0 \\
\hline Bagasse kenna mix & 211.8 & 211.8 & 211.8 \\
\hline Lysine & 30.0 & 30.0 & 30.0 \\
\hline Glycine & 10.0 & 10.0 & 10.0 \\
\hline Methionine & 5.0 & 5.0 & 5.0 \\
\hline Vitamin premix & 5.0 & 5.0 & 5.0 \\
\hline Total $(\mathrm{g})$ & 1000 & 1000 & 1000 \\
\hline
\end{tabular}

Seven fish specimen was collected from each experimental group and washed in tap dechlorinated water then fish was weighed and slaughtered by giving a longitudinal cut from the ventral side to remove viscera. Fish flesh from the dorso-lateral side was removed and analyzed for its moisture, protein and lipid contents. Liver and ovary were also removed for proximate analysis by following methods described by [12].

\subsection{Statistical analysis}

"The data were subjected to statistical analysis by using Minitab software. The differences among treatments were tested using ANOVA followed by the DMR test."

\section{RESULTS AND DISCUSSION}

The final average body weight after trial 12 weeks of Oreochromis niloticus in experimental diets and reference diets were recorded as $110.88 \pm 2.58,102.66 \pm 3.29$ and $87.72 \pm 3.66 \mathrm{~g}$ and $86.40 \mathrm{~g}$ 's $\pm 2.75 \mathrm{~g}$, respectively. The fish fed with commercial diet exhibited higher water contents compared to the experimental feeds. In $O$. niloticus total protein content was recorded as $63.44 \pm 3.81,64.03 \pm 4.18$, $62.75 \pm 3.65$ and $63.02 \pm 3.42$ percent on dry matter basis after feeding with feed A, B, $\mathrm{C}$ and $\mathrm{D}$, respectively. The minimum and maximum protein contents were recorded in fish fed with diet $\mathrm{C}$ and diet $\mathrm{B}$, respectively (Table 3). There was non-significant $(\mathrm{P}<0.05)$ difference in protein contents in the fish fed with diets $\mathrm{A}, \mathrm{C}$ and $\mathrm{D}$. The fish fed with diet $\mathrm{B}$ exhibited higher protein contents compared to the experimental feed. In $O$. niloticus total fat content was recorded as $3.12 \pm 0.38,1.76 \pm 0.41$ $1.81 \pm 0.26$ and $2.32 \pm 0.39$ percent on dry matter basis after feeding with feed A, B, C and $\mathrm{D}$, respectively. The minimum and maximum fat contents were recorded in fish fed with diet $\mathrm{B}$, and diet A, respectively (Table 3$)$. There was significant $(\mathrm{P}<0.05)$ difference in total fat contents in the fish fed with diets A, B, C and D. The fish fed with diet A exhibited higher total fat contents compared to the experimental feeds. In O. niloticus total ash content was recorded as $26.48 \pm 2.72,26.10 \pm 3.44,26.32 \pm 3.62$ 
and 26.03 \pm 3.51 percent on dry matter basis after feeding with feed $\mathrm{A}, \mathrm{B}, \mathrm{C}$ and $\mathrm{D}$, respectively. The minimum and maximum ash contents were recorded in fish fed with diet $\mathrm{D}$ and $\operatorname{diet} \mathrm{A}$, respectively (Table 3$)$. There was non-significant $(\mathrm{P}<0.05)$ difference in total ash contents in the fish fed with an experimental feed and diet D. In $O$. niloticus carbohydrate content was recorded as $1.64 \pm 0.22,2.21 \pm 0.41$, $2.82 \pm 0.51$ and $1.21 \pm 0.0 .33$ percent on dry matter basis after feeding with feed A, B, $\mathrm{C}$ and $\mathrm{D}$, respectively. The minimum and maximum ash contents were recorded in fish fed with diet $\mathrm{D}$ and diet $\mathrm{C}$, respectively (Table 3 ). There was significant ( $\mathrm{P}$ $<0.05)$ difference in carbohydrate contents in all the experimental and control diet for accumulation of carbohydrate. The fish fed with diet $\mathrm{C}$ accumulated maximum ash contents compared to the other experimental feeds.

Liver and gonads of $O$. niloticus was selected to study an effect of replacement of fishmeal in the experimental feeds on their proximate composition. In liver and ovary of $O$. niloticus protein content was recorded as 53.78 $\pm 3.11,54.17 \pm 3.72$, $54.77 \pm 3.69$ and $52.99 \pm 4.02$ and $53.78 \pm 3.11,54.17 \pm 3.72,54.77 \pm 3.69$ and $52.99 \pm 4.02$ percent on dry matter basis after feeding with feed $\mathrm{A}, \mathrm{B}, \mathrm{C}$ and diet $\mathrm{D}$, respectively. The minimum and maximum protein contents were recorded in the liver and ovary of fish fed with diet D and C and D and C, respectively (Table 4). There was nonsignificant $(\mathrm{P}<0.05)$ difference in protein contents in the liver and ovary of fish fed with A, B and C. In liver and ovary of $O$. niloticus fat content was recorded as $30.31 \pm 2.31,28.50 \pm 2.90,28.29 \pm 2.82$ and $32.60 \pm 3.05$ and $25.63 \pm 1.16,20.30 \pm 1.24$, $22.64 \pm 1.40$ and $20.18 \pm 1.51$ percent on dry matter basis after feeding with feed A, B, $\mathrm{C}$ and diet $\mathrm{D}$, respectively. The minimum and maximum protein contents were recorded in the liver and ovary of fish fed with diet $\mathrm{B}$ and $\mathrm{D}$ and $\mathrm{D}$ and $\mathrm{C}$, respectively (Table 4$)$. There was non-significant $(\mathrm{P}<0.05)$ difference in protein contents in the liver and ovary of fish fed with B, C and D and B and C, respectively. In liver and ovary of $O$. niloticus ash content was recorded as $5.82 \pm 0.77,5.61 \pm 0.62$, $6.42 \pm 0.51$ and $5.23 \pm 0.42$ and $5.89 \pm 0.33,4.85 \pm 0.40,6.15 \pm 0.18$ and $6.29 \pm 0.52 \mathrm{a}$ percent on dry matter basis after feeding with feed A, B, C and diet D, respectively. The minimum and maximum ash contents were recorded in the liver and ovary of fish fed with diet D and C and B and D, respectively (Table 4). In liver and ovary of O. niloticus carbohydrate content was recorded as $9.12 \pm 1.02,11.62 \pm 1.41,9.32 \pm 1.33$ and $8.16 \pm 1.03$ and $17.05 \pm 1.15,18.43 \pm 1.66,16.21 \pm 1.51$ and $13.86 \pm 1.70$ percent on dry matter basis after feeding with feed A, B, C and diet D, respectively. The minimum and maximum carbohydrate contents were recorded in the liver and ovary of fish fed with diet D and B and D and A, respectively (Table 4).

The inclusion of alternative protein sources in the artificial feed for freshwater species like tilapia to reduce the cost of feed and production costs is commercially important. But, optimization of feed content with alternative source is very important which favor the growth of fish and do not effect on the body composition of fish. In this study, the $O$. niloticus fed with the feed containing 11.38, 15.17 and $18.97 \%$ of fishmeal in feed A, B and C. A reference commercial diet D was purchased from the local manufacturer Arassco Limited, Saudi Arabia. All the four feeds were having 40 $\%$ crude protein (Table 2 ). In this study 40 and $20 \%$ replacement of fishmeal was made compared to feeding in C. carpio. In this experiment the experimental tilapia, which were fed with the fishmeal replaced with $20 \%$ of diet C in feed B with other plant sources of protein, had shown significantly higher total protein in their muscle compared to diet A, C and control. In O. niloticus minimum lipid content was recorded in fish fed with diet B compared to A, C and commercial feed. This was in accordance with the findings of [13] who reported that L. Schmitti larvae, when fed with $A$. platensis added diet, showed higher growth performance and body proximate composition. [14] also reported significantly improved growth and body composition in $M$. rosenbergii PL when fed with a meal containing Artemia nauplii enriched with 
Effect replacement of fishmeal on proximate composition

Arthrospira. [15] mentioned that fishmeal replacement with plant sources up to 20\%, significantly improved the growth performance, nutritional utilization and body proximate composition in $C$. carpio. It has significantly affected the protein and lipid contents in the fish's body. Our results are in line with the findings of above mentioned workers. It may be due to the reason of, soybean meal, corn gluten and bagasse kenna mix have a good quantity of protein and all the essential amino acids and fatty acids, etc., [16-17]. On the other hand, changes in the protein and lipid contents in the fish muscle might be linked to changes in their synthesis, deposition rate in muscle, liver and ovary [17-19] (The muscle protein, lipid, moisture and ash contents were not significantly affected by the replacement of fishmeal up to $40 \%$ with alternative plant sources. Similar findings were also reported in the muscle proximate composition of Nile tilapia [21-22]. Another experiment in which fishmeal was used as the main protein source to study the dietary protein requirement of fish exhibited that body ash content was not affected by the dietary protein level [23-24]. The lipid level was observed to decrease in the O. niloticus, when fed with the diet containing $20 \%$ replacement of fishmeal in feed B. This may be due to the lipid content which was lower in soybean meal and corn gluten meal instead with the fishmeal. Liver and Ovary exhibited similar trends in their proximate composition as in muscle.

Table 2: Chemical composition of experimental feeds

\begin{tabular}{|r|r|r|r|l|}
\hline Chemical constituents & \multicolumn{1}{l|}{ Feed-A } & Feed-B & Feed-C & Feed-D \\
\hline Dry matter & $90.19 \pm 2.66 \mathrm{~b}$ & $97.77 \pm 2.71 \mathrm{a}$ & $97.11 \pm 2.54 \mathrm{a}$ & $93.09 \pm 0.8 \mathrm{~b}$ \\
\hline Moisture & $9.82 \pm 1.62 \mathrm{a}$ & $2.24 \pm 1.66 \mathrm{c}$ & $2.90 \pm 1.22 \mathrm{c}$ & $6.91 \pm 0.28 \mathrm{~b}$ \\
\hline Crude protein & $40.06 \pm 2.36 \mathrm{a}$ & $40.05 \pm 2.70 \mathrm{a}$ & $40.02 \pm 2.74 \mathrm{a}$ & $40.36 \pm 2.76 \mathrm{a}$ \\
\hline Crude fat & $1.93 \pm 0.28 \mathrm{~b}$ & $2.28 \pm 0.64 \mathrm{a}$ & $2.25 \pm 0.77 \mathrm{a}$ & $1.84 \pm 1.32 \mathrm{~b}$ \\
\hline Total carbohydrates & $33.63 \pm 3.16 \mathrm{~b}$ & $41.53 \pm 3.46 \mathrm{a}$ & $39.88 \pm 2.88 \mathrm{a}$ & $34.63 \pm 0.19 \mathrm{~b}$ \\
\hline Ash & $6.47 \pm 0.81 \mathrm{a}$ & $6.94 \pm 0.92 \mathrm{a}$ & $7.71 \pm 0.68 \mathrm{a}$ & $5.71 \pm 0.62 \mathrm{~b}$ \\
\hline Fiber & $7.18 \pm 1.02 \mathrm{a}$ & $6.98 \pm 1.12 \mathrm{a}$ & $7.06 \pm 1.41 \mathrm{a}$ & $6.12 \pm 0.13 \mathrm{~b}$ \\
\hline Gross energy (Kcal/g) & $340.24 \pm 4.6$ & $340.80 \pm 5.22$ & $340.57 \pm 6.23$ & $316.52 \pm 5.24$ \\
\hline
\end{tabular}

Means with different letters for each fish in a column are highly significantly different $(\mathrm{P}<0.01)$. S.E. $=$ standard error

Table 3: Proximate composition from dry matter of muscle of Oreochromis niloticus

Fed with different experimental diets

\begin{tabular}{|r|c|c|c|c|}
\hline $\begin{array}{l}\text { Chemical constituent } \\
(\%)\end{array}$ & Feed-A & Feed-B & Feed-C & Reference feed- D \\
\hline Crude protein & $63.44 \pm 3.81 \mathrm{~b}$ & $64.03 \pm 4.18 \mathrm{a}$ & $62.75 \pm 3.65 \mathrm{~b}$ & $63.02 \pm 3.42 \mathrm{~b}$ \\
\hline Fat & $12.12 \pm 0.38 \mathrm{a}$ & $10.76 \pm 0.41 \mathrm{c}$ & $11.81 \pm 0.26 \mathrm{c}$ & $12.32 \pm 0.39 \mathrm{~b}$ \\
\hline Ash & $23.48 \pm 2.72 \mathrm{~b}$ & $23.10 \pm 3.44 \mathrm{~b}$ & $24.32 \pm 3.62 \mathrm{a}$ & $23.03 \pm 3.51 \mathrm{a}$ \\
\hline Carbohydrates & $1.64 \pm 0.22 \mathrm{c}$ & $2.21 \pm 0.41 \mathrm{~b}$ & $2.82 \pm 0.51 \mathrm{a}$ & $1.21 \pm 0.0 .33 \mathrm{~d}$ \\
\hline
\end{tabular}

Means with different letters for each fish in a column are highly significantly different $(\mathrm{P}<0.01)$. S.E. =standard error

Table 4: Proximate composition from dry matter of liver and ovary of Oreochromis niloticus Fed with different experimental diets

\begin{tabular}{|r|l|l|l|l|}
\hline $\begin{array}{l}\text { Chemical constituent } \\
(\%)\end{array}$ & Feed-A & Feed-B & Feed-C & $\begin{array}{l}\text { Reference feed- } \\
\text { D }\end{array}$ \\
\hline Liver & \multicolumn{5}{|l|}{} \\
\hline Crude protein & $53.78 \pm 3.11 \mathrm{a}$ & $54.17 \pm 3.72 \mathrm{a}$ & $54.77 \pm 3.69 \mathrm{a}$ & $52.99 \pm 4.02 \mathrm{~b}$ \\
\hline Fat & $30.31 \pm 2.31 \mathrm{a}$ & $28.50 \pm 2.90 \mathrm{~b}$ & $28.29 \pm 2.82 \mathrm{~b}$ & $32.60 \pm 3.05 \mathrm{~b}$ \\
\hline
\end{tabular}




\begin{tabular}{|r|c|c|c|l|}
\hline Ash & $5.82 \pm 0.77 \mathrm{~b}$ & $5.61 \pm 0.62 \mathrm{~b}$ & $6.42 \pm 0.51 \mathrm{a}$ & $5.23 \pm 0.42 \mathrm{c}$ \\
\hline Carbohydrates & $9.12 \pm 1.02 \mathrm{~b}$ & $11.62 \pm 1.41 \mathrm{a}$ & $9.32 \pm 1.33 \mathrm{~b}$ & $8.16 \pm 1.03 \mathrm{c}$ \\
\hline Ovary & \multicolumn{5}{|l|}{} \\
\hline Crude protein & $52.28 \pm 2.90 \mathrm{~b}$ & $56.33 \pm 2.77 \mathrm{a}$ & $55.47 \pm 2.54 \mathrm{a}$ & $49.93 \pm 2.33 \mathrm{~b}$ \\
\hline Fat & $25.63 \pm 1.16 \mathrm{~b}$ & $20.30 \pm 1.24 \mathrm{c}$ & $22.64 \pm 1.40 \mathrm{c}$ & $20.18 \pm 1.51 \mathrm{a}$ \\
\hline Ash & $5.89 \pm 0.33 \mathrm{a}$ & $4.85 \pm 0.40 \mathrm{~b}$ & $6.15 \pm 0.18 \mathrm{a}$ & $6.29 \pm 0.52 \mathrm{a}$ \\
\hline Carbohydrates & $17.05 \pm 1.15 \mathrm{a}$ & $18.43 \pm 1.66 \mathrm{a}$ & $16.21 \pm 1.51 \mathrm{a}$ & $13.86 \pm 1.70 \mathrm{~b}$ \\
\hline
\end{tabular}

Means with different letters for each fish in a column are highly significantly different $(\mathrm{P}<0.01)$. S.E. $=$ standard error

\section{CONCLUSION}

Our findings indicated that, alternative plant sources like corn gluten meal, soybean meal and bagasse kenna mix can be successfully used for the partial replacement of fishmeal protein in fish feed. It has been concluded that $20-40 \%$ level of fishmeal can be replaced in the diet of fish without having any impact on growth and chemical composition of muscle.

\section{ACKNOWLEDGEMENT}

The authors would like to their sincere appreciation to the Deanship of Scientific Research at King Saud University for its funding of this research through the Prolific Research Group Project No. PRG- 1436-011.

\section{REFERENCES}

[1] Mahboob S, Sheri AN. (2002) Influence of fertilizers and artificial feed on the total dressing losses, meat: bone ratios, specific gravity and density of fish and regression studies of dry weight of planktonic biomass on physico-chemical parameters. J Aqua Trop. 2002; 17: 43-58.

[2] Lim C, Webster CD, Lee CS. (Eds.). Alternative protein sources in aquaculture diets. The Haworth Press, New York, NY. 2008; 571 pp.

[3] Choo PS, Williams MJ. (2003). Fisheries production in Asia: Its role in food security and nutrition. The World Fish Cent Quart. 2003; 26(2): 11-16.

[4] Sandhu GS. A Textbook of Fish and Fisheries. Dominant Publishers and Distributors, New Delhi: 2005; 39-40.

[5] Razvi M (2006). Lahore-absolutely fishy: Nutritional value. The Review, Dawn. 2006; $12-13$

[6] Salim M. Role of fish as food to human nutrition. International conference on Solving problems of Freshwater Fish Farming in Pakistan" November 27-28 2006. UVAS, Lahore.2006; 20 pp

[7] Yildrim O. Aquafeed industry in Turkey: its aquafeed projections towards the year 2015. Turk J Fish Aqua Sci. 2008; 8: 93-98.

[8] Gatlin III DM, Barrows FT, Brown P, Dabrowski K, Gaylord TG, Hardy RW, Herman E, Hu G, Krogdahl A, Nelson R, Overturf K, Rust M, Sealey W, Skonberg D, Souza EJ, Stone D, Wilson R, Wurztel E. Expanding the utilization of sustainable plant products in aquafeeds: a review. Aqua Res. 2007; 38: 551-579.

[9] Glencross B, Evans D, Dods K, Mcafferty P, Hawkins W, Maas R, Sipsas S. Evaluation of the digestible value of lupin and soybean protein concentrates and isolates when fed to rainbow trout, Oncorhynchus mykiss, using either stripping or settlement fecal collection methods. Aquaculture2005; 245: 211-220.

[10] Naylor R, Hardy R, Bureau D, Chiu A, Elliott M, Farrell A, Forster I, Gatlin D, Goldberg R, Hua K, Nichols P, Feeding aquaculture in an era of finite resources. Proceedings of the National Academy of Sciences of the United States of America. 2009; 106: 1510315110 . 
Effect replacement of fishmeal on proximate composition

[11] Mahboob S, Al-Balawi HFA, Al- Ghanim KA Al-Misned F, Ahmad Z. Study on complete replacement of fish meal by plant sources meal as a dietary protein for Labeo rohita and Ctenophyryngodon idella. Pak J Zool. 2014; 46(5): 1391-1397.

[12] AOAC (Association of official analytical Chemistry). Official methods of analysis, 18th ed. WILLIAMS, S.ed., AOAC, Inc., Arlington, Virginia. 1995.

[13] Jaime CB, Hernández-Llamas A, Garcia-Galano T, Villarreal H. Substitution of Chaetoceros muelleri by Spirulina platensis meal in diets for Litopenaeus schmitti larvae. Aquaculture 2006; 260: 215-220.

[14] Bhavan PS, Devi VG, Shanthi R, Radhakrishnan S, Poongodi R. Basicbiochemical constituents and profiles of amino acids in the post larvae of Macrobrachium rosenbergii fed with Spirulina and yeast enriched Artemia J Sci. Res. 2010; 2 (3): 539-549.

[15] Abdulrahman NM, Hamad Ameen HJ. Replacement of fishmeal with hmicroalgae Spirulina on common carp weight gain, meat and sensitive composition and survival. Pak $\mathbf{J}$ Nutr.2014; 13: 93-98.

[16] James R, Sampath K. Effect of animal and plant protein diets on growth andreproductive performance in an ornamental fish, Xiphophorus helleri. Indian J Fish. 2004; 51: 75-86.

[17].James R, Sampath K, Thangarathinam R, Vasudevan I. Effect of dietary Spirulina level on growth, fertility, coloration and leucocyte count in red swordtail, Xiphophorus helleri. Israeli J Aquacult. 2006; 58,: 97-104.

[18] Kyewalyanga MS. Assessment of types and abundance of live food for fishfarming in Makoba Earthen Ponds, Zanzibar, Tanzania. West. Indian Ocean J.Mar. Sci. 2003; 2, 45-56.

[19] Abdel-Tawwab M, Khattab AE, Ahmad MH, Shalaby AME.Compensatory growth, feed utilization, whole body composition and hematological changes in starved juvenile Nile tilapia, Oreochromis niloticus (L.). J Appl Aquacult. 2006; 18: 17-36.

[20] Karakatsouli N. An overview of the use of fatty acids in fish farmingresearch during the last decade, with particular emphasis on fish quality. J World Aquacult. Soc. 2012; 43: 291320.

[21] Mahboob S, Rauf A, Ashraf M, Sultana T, Sultana S, Jabeen F, Rajoka MI, ,Alkaham Al-Balawi HF, Al-Ghanim KA. High density growth andcrude protein productivity of a thermo tolerant Chlorella vulgaris: production kinetics and thermo dynamics. Aquacult Int. 2012; 20: 455-466.

[22] Dawah MA, Khater AM, Shaker IMA, Ibrahim NA. Production of Scenedesmus bijuga (Chlorophyceae) in large scale in outdoor tanks and its use in feeding monosex Nile tilapia (Oreochromis niloticus) fry. J. Egypt. Acad. Soc. Environ. Develop. B Aquacult. 2002; 2, $113-125$.

[23] Shiau SY, Huang SL. Optimal dietary protein level for hybrid tilapia (Oreochromis niloticus $\cdot$ X O. aureus) reared in seawater. Aquaculture. 1989; 81: 119-127.

[24] Yang SD, Liou CH, Liu FG. Effects of dietary protein level on growth performance, carcass composition and ammonia excretion in juvenile silver perch (Bidyanus bidyanus). Aquaculture. 2002; 213: 363-372.

[25] Yang SD, Lin TS, Liou CH, Peng HK. Influence of dietary protein levels on growth performance, carcass composition and liver lipid classes of juvenile Spinibarbus hollandi (Oshima). Aquac Res. 2003; 34, 661-666. 